\title{
Groundwater flow modeling for impact assessment of port dredging works on coastal hydrogeology in the area of Al-Wakrah (Qatar)
}

\author{
Fethi Lachaal ${ }^{1} \cdot$ Slim Gana ${ }^{2}$
}

Received: 23 October 2016/Accepted: 31 October 2016/Published online: 12 November 2016

(C) Springer International Publishing Switzerland 2016

\begin{abstract}
This paper presents the impact assessment of the port dredging works on aquifer's hydrogeology in the area of Al-Wakrah Economic Port Zone 3 in Qatar (QEZ3) project using groundwater numerical model (MODFLOW3D). The QEZ3 model is used to estimate the groundwater flow system and the groundwater levels in the study area, during the dredging and dewatering period. Specially, we focused on the impact of dredged and dewatering water stored in two programmed stilling basins. The modeling period is about 6 years from August 2010 to May 2015 according to the available data and the project phasing. Three scenarios are chosen according to the time schedule of QEZ3 project. The model gives a high piezometric level of more than $2.5 \mathrm{~m} \mathrm{CD}$ (chart datum) located in stilling basins area, which can will cause water resurgence and groundwater flooding. As solution, using the model results we proposed to change the programmed discharge areas.
\end{abstract}

Keywords Dredging · Hydrogeology · Groundwater modelling · Dewatering · Groundwater MODFLOW

Fethi Lachaal

lachaalfethi@yahoo.fr; fethi.lachaal@certe.rnrt.tn

1 Georesources Laboratory, Water Research and Technology Centre, Borj Cedria Ecopark, PO Box 273, Soliman 8020, Tunisia

2 National Agronomic Institute of Tunisia, 43 Avenue Charles Nicolle, Mahrajène, 1082 Tunis, Tunisia

\section{Introduction}

Urbanization occupies a puzzling position in country development and growth, global economic development, energy consumption, natural resource use, and human wellbeing (McDonald et al. 2011, 2014; Uddameri et al. 2014; Mondal et al. 2015; Pandey and Joshi 2015; Jain et al. 2016). In the 21 st century, urbanization has experienced strong growth, especially in coastal regions. In this case, construction in the coastal region requires dredging and dewatering works which cause an environment perturbation (Wang et al. 2013, 2014, 2016; Xu et al. 2016; Chambers et al. 2016; Khadri and Chaitanya 2016).

Groundwater flow modeling has become an invaluable tool for assessing the impact of existing and future activities on groundwater resources (Lachaal et al. 2012, 2013; Jothibasu and Anbazhagan 2016; Seyedmohammadi et al. 2016; Sajil Kumar 2016; Ehteshami et al. 2016; Gopinath et al. 2016; Mokarram 2016; Khorasani et al. 2016) especially for the groundwater systems evolution caused by urbanization and growth (Calderhead et al. 2012). Previous studies show the significant contribution of groundwater modeling to estimate the mine and tunnel construction impact in groundwater situation and quality (JaramilloNieves and Ge 2012; Hussien 2013; Chen and Jiao 2014; Jahanshahi and Zare 2015; Pujades et al. 2016), and to estimate groundwater quality in relation with the port construction (Zammouri et al. 2014).

Dredging and dewatering activities planned in the AlWakrah Economic Port Zone 3 in Qatar (QEZ3, Qatar) construction requires careful groundwater management. In addition the groundwater rise that can be resulted by the dewatering activity can induce the flooding of some area outside the project area. This problem was observed in the 
Qatar New Port project (NPP), located further south of QEZ3 project (Fig. 1).

The QEZ3 is programmed to be constructed in the Messaieed/Al Wekrah region (center East Qatar) (Fig. 2). It is a self-contained development with industrial and residential facilities; it will be located adjacent to the NPP port. The QEZ3 will be an important gateway into Qatar.

The groundwater numerical model was developed to assess the initial status of the aquifers' hydrogeology QEZ3 project area before the commencement of the dredging

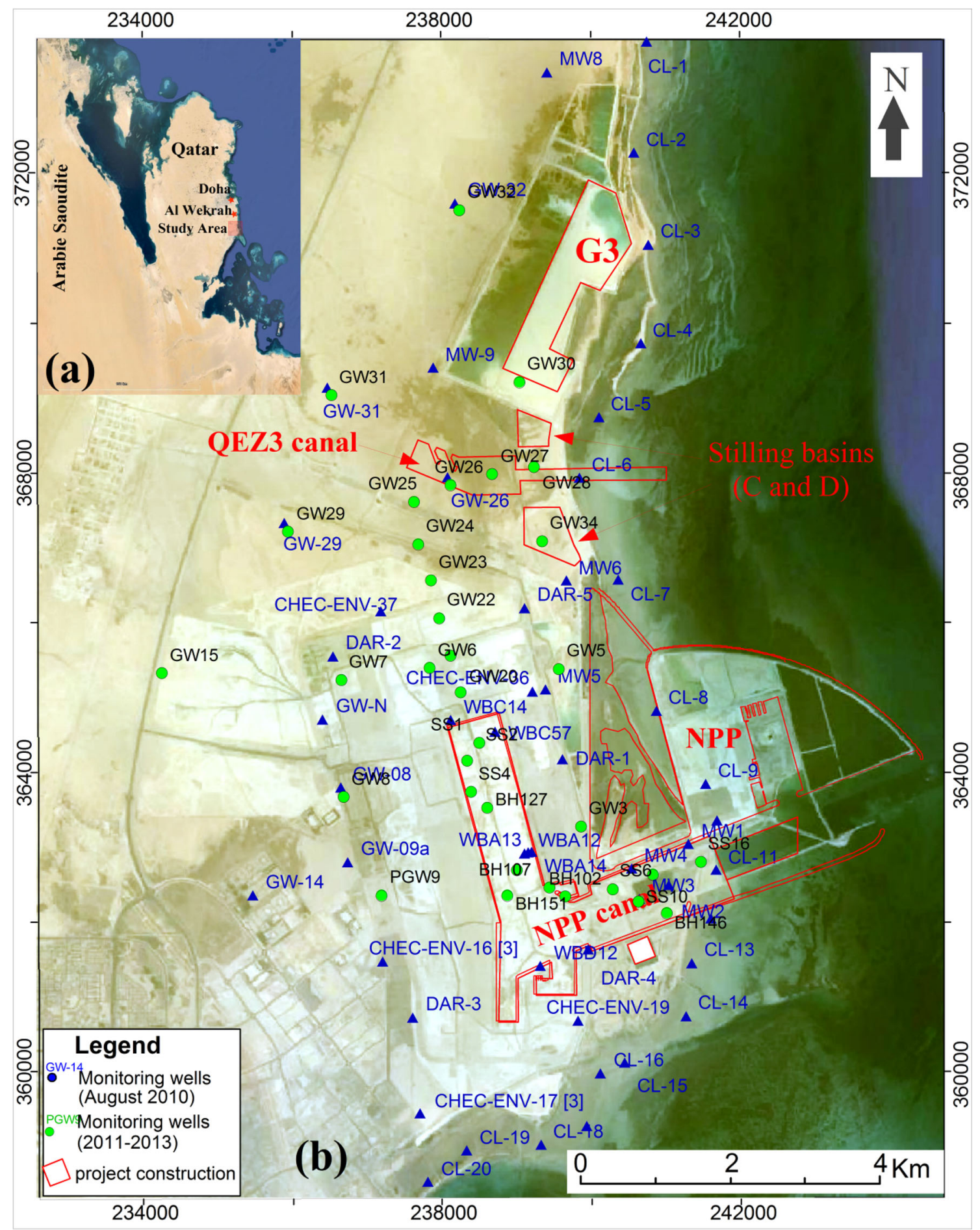

Fig. 1 Location map of the study area. a Qatar general location map. b Messaieed/Al Wekrah plain location and used data: position of Groundwater monitoring wells and constructions in the QEZ3 project area 
Fig. 2 Conceptual 3D-model of the Messaieed/Al Wekrah aquifer

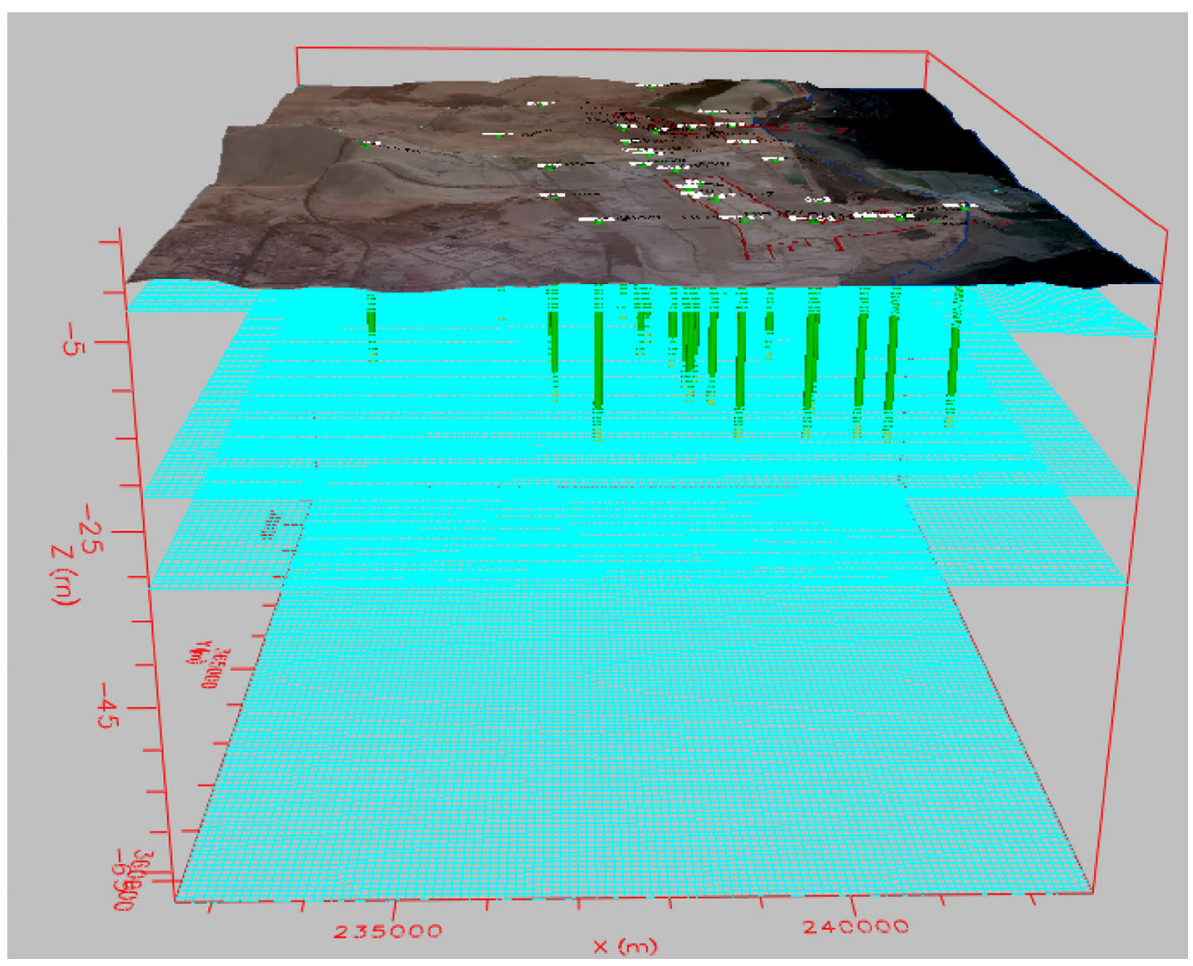

works and then, to assess the impact of dredged water stored in the two stilling basins on groundwater level in order to prevent seepage and flooding, during the progress of the dredging works.

\section{Materials and methods}

\section{Hydrogeology description of study area}

Qatar is a small peninsula in the Persian Gulf, with an area of approximately $11,590 \mathrm{~km}^{2}$ (CIA 2013) including a number of small offshore islands (FAO 2015). The Qatar Peninsula is located in the Arabian Gulf at the northeastern margin of the Arabian Peninsula land mass (Mohamed Ashour 2013). Qatar has arid desert climate that is characterized by high temperatures during summer $\left(>40{ }^{\circ} \mathrm{C}\right)$, scanty rainfall with an annual average of about $82 \mathrm{~mm}$ over the period 1999-2008 and, a high evaporation rates with an annual average of $2200 \mathrm{~mm}$ (UN-Qatar 2009), a very strong winds, and high relative humidity. Qatar is a water resources stressed country and groundwater forms the main natural internal water resource (Shomar et al. 2014; Kuiper et al. 2015; FAO 2015; Baalousha 2016a, b).

The study area covered the Messaieed/Al Wekrah region that is located in the center East Qatar, approximately $1300 \mathrm{~m}$ from the coast of Arabian Gulf, southeast of Doha, Qatar. The hydrogeologic units on the
Messaieed/Al Wekrah region is composed by two main aquifers shallow and deep aquifer. The upper aquifer correspond to the Simsima formation and is formed within the limestone and overlying sediments. The deep aquifer is formed by Rus formation. The two aquifers are typically separated by the relatively impermeable and continuous Midra shale.

\section{GIS database}

In order to simplify the use, the interpretation of the available hydrogeological data, and to construct the threedimensional groundwater flow numerical model, we propose to develop first a spatial database.

Numerous data from many sources and different types have been collected, homogenized and integrated in the GIS spatial database.

The required GIS data for groundwater conceptual modeling are converted to the appropriate format for numerical modeling using Arc Map 10.0. The surface elevation, the geometric boundary of the modeled aquifer, the aquifer base and top of the different aquifer layers, the QEZ3 canal and channel, the NPP canal, the two stilling basins ( $\mathrm{C}$ and $\mathrm{D})$, the $\mathrm{G} 3$ basin, and the monitoring wells positions (40 observations in August 2010, 41 observation wells covering the period from July 27, 2011 to December $22,2013)$ are saved as shape files which is compatible with the used modeling software (Fig. 1). 


\section{Climate data of rainfall}

The average annual rainfall is about $82 \mathrm{~mm} \mathrm{year}^{-1}$ and the Infiltration is $10 \%$ of the average annual rainfall. The recharge is included in the model as $8.2 \mathrm{~mm} \mathrm{year}^{-1}$. In Sabkha areas (salt lake) located outside the study area, in west direction, the recharge is set to 0 and the evaporation defined as $100 \mathrm{~mm}$ year $^{-1}$ based on the estimated value from Hashim (2009).

\section{Groundwater geometry and hydrogeological parameters}

The surface topographic level was interpolated from two recent topographic grids done in January 16, 2010 and October 2, 2010 for the QEZ3 project covering the surface located between the parallels 362,940 and 373,800 north and 258,300 and 242,700 East. For the South side and between the parallels 362,940 and 362,940 north and 232,600 and 242,700 East we imposed a topographic level of $+2.5 \mathrm{~m} \mathrm{CD}$ (chart datum) $=1.2 \mathrm{~m} \mathrm{ZQNHD}$, that is will not affect the result because this area is so far to the project QEZ3 canal area.

The aquifer geometry is defined using the wells logging, geotechnical investigation and geophysics data done in the region to QEZ3 project. The aquifer is considered as a multilayer system represented by four layers represented in the following Table 1 and Fig. 2.

The groundwater hydraulic conductivity and specific storage have been obtained from the pumping tests data conducted in the study area in 2011. The calculated hydraulic conductivity range from $1.0 \times 10^{-7}$ to $2.0 \times 10^{-4} \mathrm{~m} \mathrm{~s}^{-1}$. The groundwater pumping is negligible because of the water high salinity.

\section{Groundwater levels (piezometric levels)}

Two types of groundwater levels monitoring are used for the QEZ3 groundwater model. The monitoring wells are presented in Fig. 2:

- Piezometric data of August 2010 reduced from 40 piezometric observations represented in Fig. 1 are used for the steady state calibration. In fact, groundwater is poorly used because the high groundwater salinity.
- Piezometric monitoring covering the period from July 27, 2011 to December 22, 2013. 41 piezomerters are used for the transient state calibration. We note the absence of groundwater monitoring during the year of 2014. Therefore, the model calibration during this period is not verified.

\section{Governing equations and groundwater model selection}

Three-dimensional groundwater flow can be mathematically represented given the following equation Eq. (1) based on water mass balance and Darcy's law equations (Bear 1972):

$S_{s} \frac{d h}{d t}-\left[\frac{\partial}{\partial x}\left(K_{x} \frac{\partial h}{\partial x}\right)+\frac{\partial}{\partial y}\left(K y \frac{\partial h}{\partial y}\right)+\frac{\partial}{\partial z}\left(K z \frac{\partial h}{\partial z}\right)\right]=q_{s}$

where $h$ is the hydraulic head, $S_{s}$ is the specific storage, $q_{s}$ is a sink or source, and $K_{x}, K_{y}, K_{z}$ is the hydraulic conductivity in $x, y, z$ directions, respectively. For the simulating the 3-D groundwater flow system, we chose the Visual MODFLOW model (Waterloo Hydrogeologic Inc 2003). This deterministic numerical model is based on Darcy's law and mass conservation concept. It is welldocumented and extensively used all over the world, based on the horizontal and vertical discretization of the modeling domain which solves the groundwater flow equation for each cell.

The spreading range of the water seepage from sedimentation basins, its directions and its velocity in the area, are provided using module MODPATH that is incorporated in the Visual MODFLOW numerical software used to implement and simulate the 3-D QEZ3-groundwater flow system. MODPATH calculates 3D particle tracking pathlines from the simulation output obtained thanks to MODFLOW.

\section{Results and discussions}

\section{Conceptual hydrogeological model}

The Messaieed/Al Wekrah aquifer conceptual model has been constructed based on the design layout of the Qatar

Table 1 Aquifer geometry and characteristics

\begin{tabular}{llll}
\hline & Depths $(\mathrm{m} \mathrm{CD})$ & Depths (m QNHD) & $\mathrm{K}^{\text {average }\left(\mathrm{m} \mathrm{s}^{-1}\right)}$ \\
\hline Superficial deposit & Surface topographic level $\sim 3$ & Surface topographic level $\sim 1.7$ & $3.5 \times 10^{-5}$ \\
Limestone (1) & $3-22.5$ & $1.7-21.2$ & $2.0 \times 10^{-4}$ \\
Limestone (2) & $22.5-32.5$ & $21.2-31.2$ & $1.0 \times 10^{-5}$ \\
Midra shale & $32.5 \sim$ & $31.2 \sim$ & $1.0 \times 10^{-7}$ \\
\hline
\end{tabular}


New Port, QEZ3 channels and basins, stilling basins used to store dredging water, QEZ3, the groundwater piezometric and the geometric proprieties, the number of aquifer layers, the position of each layer, the flow direction, the hydraulic conductivity and specific storage of each groundwater levels. In this step, we take into consideration the canal and basin excavation that will intercept the potential seeped quantity of water from basins.

The aquifer is a multilayer system represented by four layers, formed by superficial deposit, limestone (1), limestone (2) and shale, respectively. From the East, the Sea imposes a constant head.

The hydrodynamics of the water is influenced by the aquifer geometry, the sea and the Sabkha climate is characterized by strong evaporation (Hashim 2009).

Because of the saline nature of aquifer water it is unlikely that groundwater is used for domestic, agricultural, or other purposes in the surrounding area. This is confirmed in Hashim (2009) where the area does not figure as a zone with groundwater abstractions or any other use. That is why we consider that before August 2010 the GWL is stable and The modeling period is about 6 years from August 2010 to May 2015. According to the piezometric map of August 2010 (Fig. 4), the groundwater levels vary in the study area from a low of $-1.5 \mathrm{~m}$ QNHD to a high of $+0.8 \mathrm{~m}$ QNHD (August 2010). The map shows a depression in groundwater levels to the immediate southwest of QEZ3 canal site (Fig. 1). Groundwater levels generally increase near the coast, in response to the sea water levels. An observed increase in groundwater levels toward southern areas of the NPP site (Fig. 1) may be in response to the presence of large stilling basins filled by dredged waters.

\section{Model discretisation}

The numerical model domain is assumed to be a rectangle shape $(12.1 \times 14.5 \mathrm{~km})$ and an area of $175.45 \mathrm{~km}^{2}$. It is located between the parallels 358,300 and 373,800 north and 232,600 and 244,700 East, in the Qatar National Datum 1995 coordinate system. The vertical levels is referred to the Qatar National Height Data (ZQNHD $=$ ZCD $-1.3 \mathrm{~m})$, also used in the database. The modeling grid consists of 141 rows and 121 columns. Each cell has a size of $100 \mathrm{~m} \times 100 \mathrm{~m}$ aligned to the West-East direction that coincides with the main groundwater flow direction. The grid cells are designated as "inactive" outside the model domain and as "active" inside the model domain.

\section{Boundary conditions}

It is mandatory to define the different boundary conditions for the groundwater numerical model. In the case of the
Messaieed/Al Wekrah aquifer, boundary conditions will describe the exchange of flow between the model and the external system (rainfall infiltration, Sea, the two stilling basins...).

The boundary conditions define the exchange of flow between the groundwater model and the external system. In the case of QEZ3 project model, fixed-head boundary conditions are applied to the Eastern boundary, as imposed by the Sea water resistance $(h=0 \mathrm{mQNHD})$. It can be represented in the Visual Modlow model by river boundary conditions. To the North, South, and West sides, we considered an impermeable boundaries (no-flow conditions $\frac{\mathrm{dh}}{\mathrm{dt}}=0$ ). In fact, the model aim is to study the groundwater evolution in the QEZ3 area and the aquifer limits are so far of the study area.

In addition, MEDCO (dredging company in charge of NPP) has started pumping water into G3 basin on 14 February 2013. The G3 Basin is expected to finish operating by August 2014. In this case the G3 basin imposed fixed-head boundary conditions to the aquifer ( $\mathrm{h}=5 \mathrm{~m} \mathrm{CD}=3.7 \mathrm{~m}$ QNHD) during the dredging period (from 14 February 2013 to August 2014).

Finally, the two stilling basins will impose also fixedhead boundary conditions to the aquifer ( $\mathrm{h}=7 \mathrm{~m} \mathrm{CD}=5.7 \mathrm{~m}$ QNHD) during the dredging period (from September 2014 to May 2015).

\section{Model calibration}

The calibration aims to obtain an optimal fit between the calculated and measured data, which is also an important measure for the reliability of the operational model. The calibration of the current groundwater model involved two sequential steps, detailed below.

\section{The steady state model and initial conditions}

First, the steady state model representing the state of the aquifer system before the QEZ3 canal project works. It was calibrated using the water level data from 40 observation wells measured in August 2010. The aim of this step is to understand the trend of groundwater level in the whole domain.

Meanwhile, the initial distribution of hydraulic conductivity values was estimated from pumping test conducted in the study area (Table 1). The annual averaged rainfall distributions are applied at the top surface. The infiltration rate represents the groundwater recharge, which is estimated by $10 \%$ of the precipitation $\left(82 \mathrm{~mm} \mathrm{year}^{-1}\right.$ ). In addition, an evaporation of $100 \mathrm{~mm}$ is imposed in the groundwater domain.

Figure 3 shows a scatter diagram of the observed and calculated water level in monitoring wells, with correlation 
coefficient of 0.879 . Therefore, it can be concluded from the comparisons presented here that the current numerical model provides a fair simulation of the groundwater flow. Figure 4 represents the modeled piezometric map of August 2010.

\section{Transient state simulations}

The modeling period is about 6 years from August 2010 to May 2015 in accordance with the available data. The transient model calibration was performed by simulating groundwater level changes in response to the variations of the natural and artificial recharge quantities due to the rainfall fluctuations. The transient model is based on the preliminary hydrogeological properties obtained from the steady-state calibration. The porosity for the unconfined party and specific storage for the confined party of the aquifer were arbitrary chosen.

For the transient simulations, the geometric and the hydraulic conductivities of the aquifer are the same as those used for the steady state simulations. The resulting flow field of the steady state model is used as the initial condition for the subsequent transient simulations of the flow system in response to the dynamic recharge. Analogous to the steady state simulation, the groundwater recharge is assumed as $8 \mathrm{~mm}_{\text {year }}{ }^{-1}$.

The transient model calibration is accomplished by simulating hydraulic head changes in response to changes in recharge and porosity, with regard to the time series data of water level. The comparison of calculated and measured

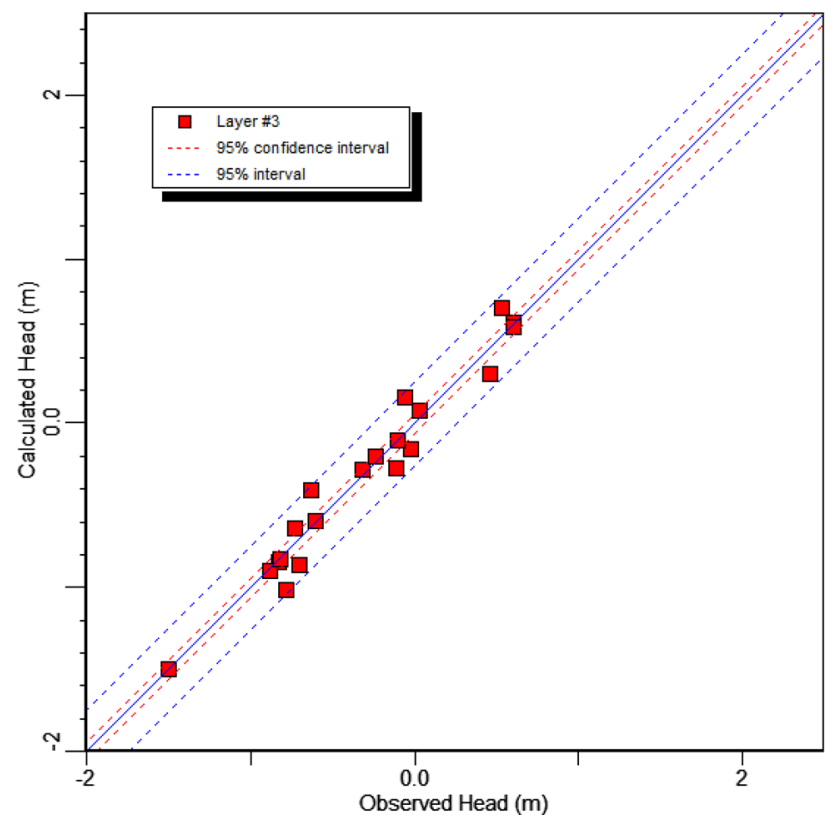

Fig. 3 Comparison of observed and calculated head in the steady state water level in observation wells are shown in Fig. 5 indicating an acceptable calibration.

\section{3-D groundwater flow numerical model scenarios and results}

The simulation period spans from August 2010 to May 2015 (Table 2). This period is fixed in relation of the time schedule of QEZ3 project.

\section{Time schedule and model scenarios}

The time schedule of QEZ3 project is pacified with different project phases (Table 2):

- MEDCO (dredging company in charge of NPP) has started pumping water into G3 on February 14, 2013 and discharging out of G3 basin to the sea on April 30, 2013. The G3 basin is expected to finish operating by August 2014.

- HBC (dredging company in charge of QEZ3) deepens basin excavation below existing groundwater level June 2014 with dewatering.

- HBC reaches final excavation level of $-7.5 \mathrm{~m}$ $\mathrm{CD}=-6.3 \mathrm{~m}$ QNHD part of the area at September 2014.

- HBC starts dredging and fill the still basin from September 2014 and completes dredging May 2015.

- NPP basin starts flooded from February 2015 for 39 days.

The model aim is to estimate the groundwater level, that is way we propose to definite the scenarios according to the time schedule of QEZ3 project. In this case we propose to study groundwater piezometric level for three scenarios.

a. Scenario 1 Scenario 1 is based in three conditions:

- G3 basin imposed fixed-head boundary conditions to the aquifer ( $\mathrm{h}=5 \mathrm{~m} \mathrm{CD}=3.7 \mathrm{~m} \mathrm{QNHD})$ during the dredging period of NPP canal (from February 14, 2013 to August 2014).

- Dewatering of the entire QEZ3 canal with $5000 \mathrm{~m}^{3} \mathrm{~h}^{-1}$.

- Dewatering from NPP basin with an average of about $6700 \mathrm{~m}^{3} \mathrm{~h}^{-1}$.

b. Scenario 2 Scenario 2 is based in three conditions:

- Dewatering of the entire QEZ3 canal with $5000 \mathrm{~m}^{3} \mathrm{~h}^{-1}$.

- Dewatering from NPP basin with an average of about $6700 \mathrm{~m}^{3} \mathrm{~h}^{-1}$.

- Stilling basins (C and D) imposed fixed-head boundary conditions to the aquifer $(\mathrm{h}=7.0 \mathrm{~m}$ $\mathrm{CD}=5.7 \mathrm{~m}$ QNHD). 


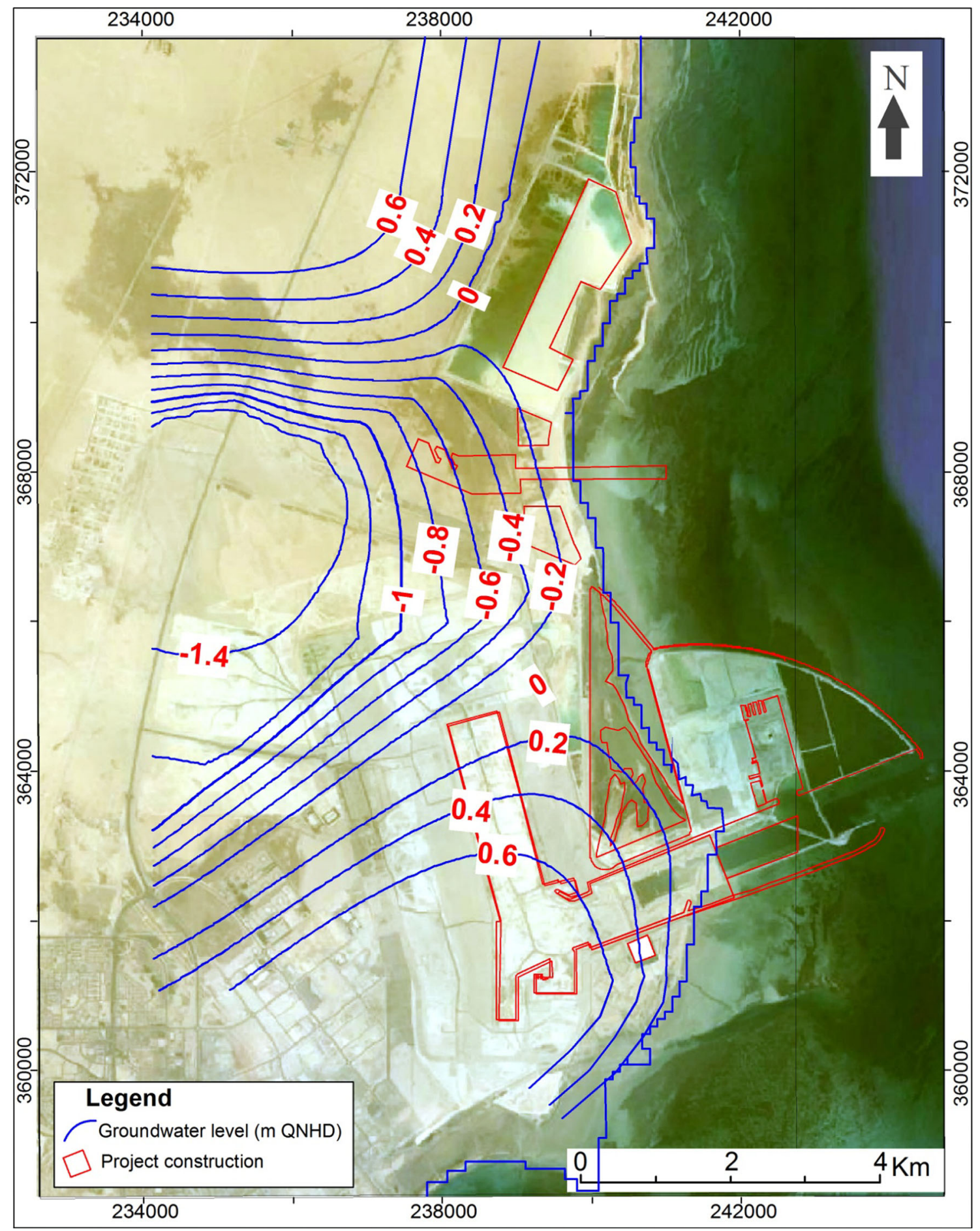

Fig. 4 Modeled groundwater piezometric map in upper aquifer (August, 2010)

c. Scenario 3 Scenario 3 is based in three conditions:

- Stilling basins (C and D) imposed fixed-head boundary conditions to the aquifer $(\mathrm{h}=7.0 \mathrm{~m}$ $\mathrm{CD}=5.7 \mathrm{~m}$ QNHD).
- Dewatering of the entire QEZ3 canal with $5000 \mathrm{~m}^{3} \mathrm{~h}^{-1}$.

- Flooding of NPP basin (recover of groundwater level approximately to $+1 \mathrm{~m} \mathrm{CD}$ ). 


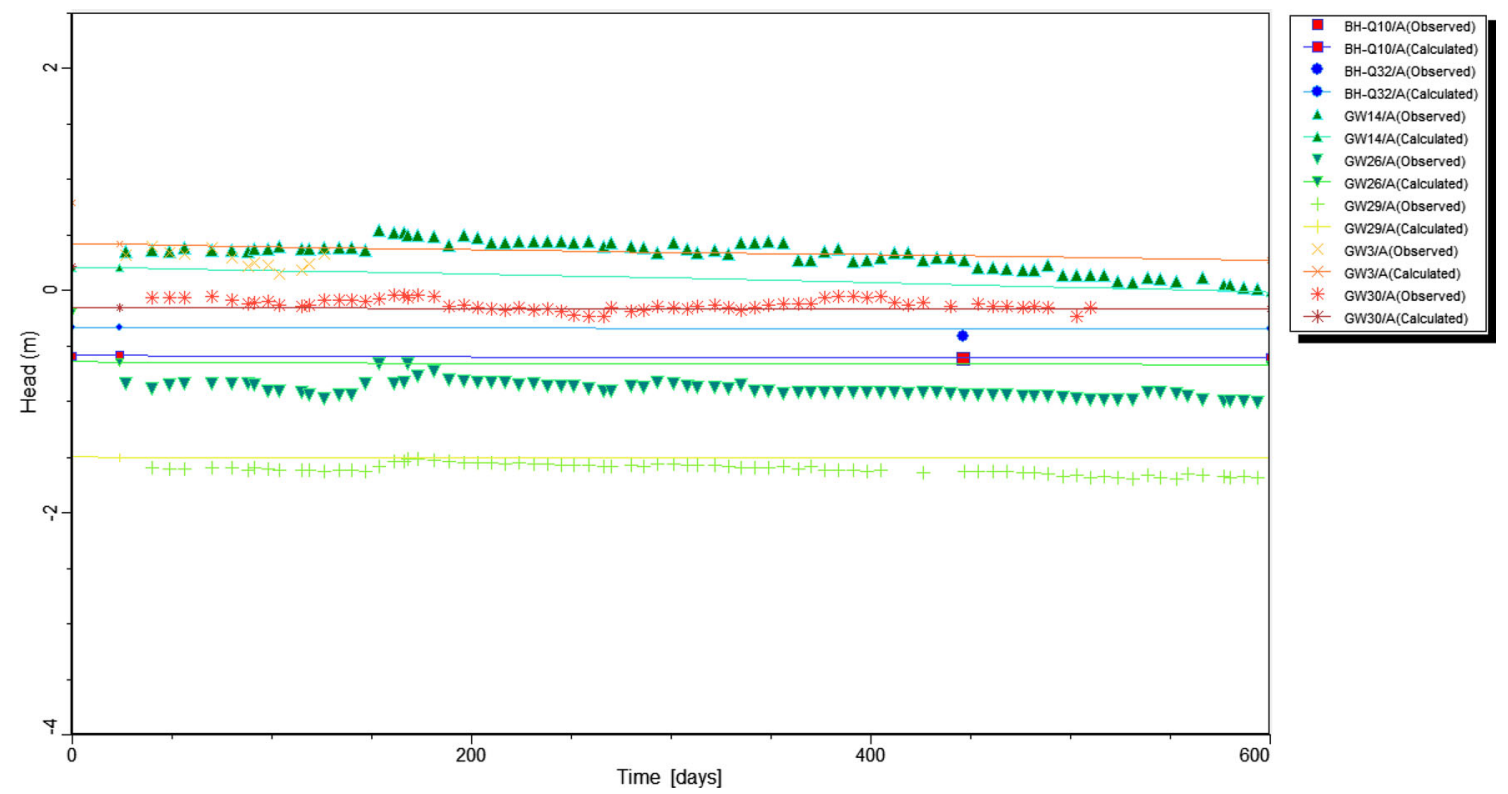

Fig. 5 Comparison of observed and calculated head in the Transient state

Table 2 QEZ-3 time schedule, and groundwater model scenarios

\begin{tabular}{|c|c|c|c|c|c|c|c|c|c|c|}
\hline \multicolumn{2}{|l|}{ Date } & $\begin{array}{l}\text { Aug 01, } \\
2010\end{array}$ & $\begin{array}{c}\text { Dec 04, } \\
2011\end{array}$ & $\begin{array}{l}\text { Feb 14, } \\
2013\end{array}$ & $\begin{array}{l}\text { Apr 30, } \\
2013\end{array}$ & $\begin{array}{l}\text { Oct 13, } \\
2013\end{array}$ & $\begin{array}{l}\text { Jun 01, } \\
2014\end{array}$ & $\begin{array}{l}\text { Sep 01, } \\
2014\end{array}$ & $\begin{array}{l}\text { Feb 01, } \\
2015\end{array}$ & $\begin{array}{l}\text { May 30, } \\
2015\end{array}$ \\
\hline \multicolumn{11}{|c|}{ Pumping water to $\mathrm{G} 3$ basin $(\mathrm{H}=5 \mathrm{~m} \mathrm{CD})$} \\
\hline \multicolumn{11}{|c|}{$\begin{array}{l}\text { Dewatering of the NPP basin (with an } \\
\text { average about } 6700 \mathrm{~m}^{3} / \mathrm{h}^{-1} \text { ) }\end{array}$} \\
\hline \multicolumn{11}{|c|}{$\begin{array}{l}\text { Dewatering of the QEZ3 canal (with an } \\
\text { average of } 5000 \mathrm{~m}^{3} / \mathrm{h}^{-1} \text { ) }\end{array}$} \\
\hline \multicolumn{11}{|c|}{$\begin{array}{l}\text { HBC's stilling basin (the water level in } \\
\text { the basin up to the level of }+7.0 \mathrm{~m} \mathrm{CD} \text { ) }\end{array}$} \\
\hline \multicolumn{11}{|l|}{ The steady state model } \\
\hline \multicolumn{11}{|c|}{$\begin{array}{l}\text { Transient state simulations (model } \\
\text { period) }\end{array}$} \\
\hline \multirow{3}{*}{ QEZ-3 model Scenarios } & Scenario 1 & & & & & & & & & \\
\hline & Scenario 2 & & & & & & & & & \\
\hline & Scenario 3 & & & & & & & & & \\
\hline
\end{tabular}

\section{Piezometric map before QEZ3 project starts}

The modeled piezometric head contour map in the QEZ3 aquifer from June 1, 2014 is illustrated in Fig. 6. Groundwater head vary from a low of $-10 \mathrm{~m}$ QNHD in the NPP basin to a high of $+3.7 \mathrm{~m}$ QNHD in the G3 basin. Water flow converges from the G3 basin where it is imposed a fixed head of $3.7 \mathrm{~m}$ QNHD. The fixed head imposed in the G3 basin causes a high piezometric zone characterized by piezometric varying between 3.7 and $1 \mathrm{~m}$ QNHD.

The watering activities operate in the NPP basin induced a piezometric depression of less than $-10 \mathrm{~m}$ QNHD. The most important water flow velocities is from the G3 basin to the sea $\left(0.00018 \mathrm{~m} \mathrm{~s}^{-1}\right)$.

\section{Scenario 1}

Scenario 1 starts in June 1, 2014 and stops in September 1, 2014. It is characterized by three conditions: (1) G3 basin imposed fixed-head boundary conditions to the aquifer $(\mathrm{h}=5 \mathrm{~m}$ $\mathrm{CD}=3.7 \mathrm{~m}$ QNHD), (2) dewatering of the entire QEZ3 canal $\left(5000 \mathrm{~m}^{3} \mathrm{~h}^{-1}\right.$ which is estimation), and (3) dewatering of the NPP basin (the average is about $6700 \mathrm{~m}^{3} \mathrm{~h}^{-1}$ ). The groundwater situation in the end of this period is characterized by the modeled piezometric map of Fig. 7. 


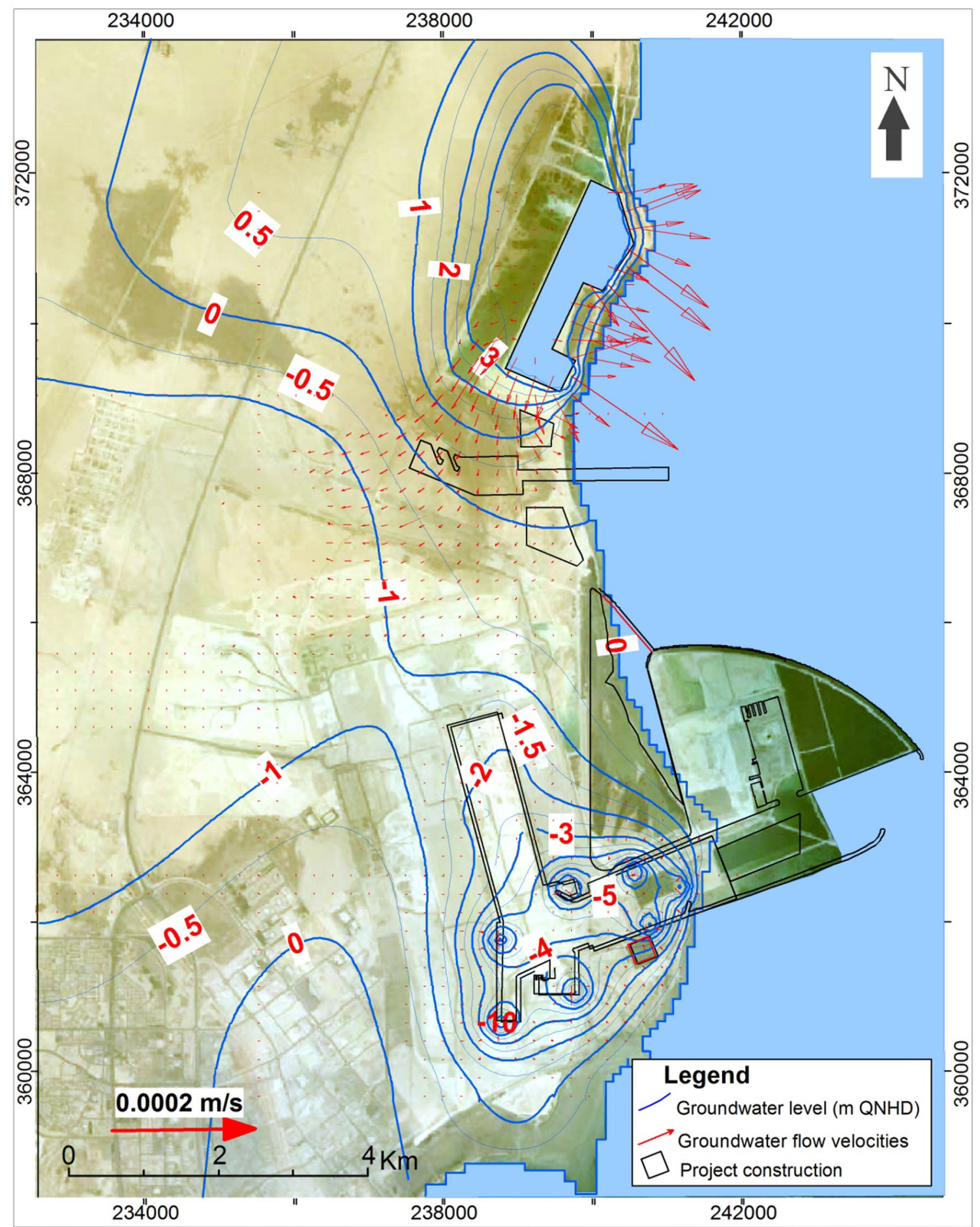

Fig. 6 Modeled groundwater piezometric map and presentation of water flow velocities in upper aquifer before HBC deepens basin excavation and dewatering (June 1,2014), showing the directions and

The modeled piezometric level varies between $-10 \mathrm{~m}$ QNHD in the NPP basin to $3.7 \mathrm{~m}$ QNHD in the G3 basin. The water flow converges from G3 to the QEZ3 canal and the NPP canal. The piezometric map is characterized by the presence of two piezometric depressions. The first the velocity of groundwater in the area of Stilling Basins (the maximum velocity calculated by the model is $0.00018 \mathrm{~m} \mathrm{~s}^{-1}$ )

depression is located in the NPP basin with piezometric level that can be less than $-10 \mathrm{~m}$ QNHD. The second piezometric depression is observed in the QEZ3 canal, that is explained by the dewatering of the QEZ3 Canal $\left(5000 \mathrm{~m}^{3} \mathrm{~h}^{-1}\right)$ influence. The high piezometric zone is 


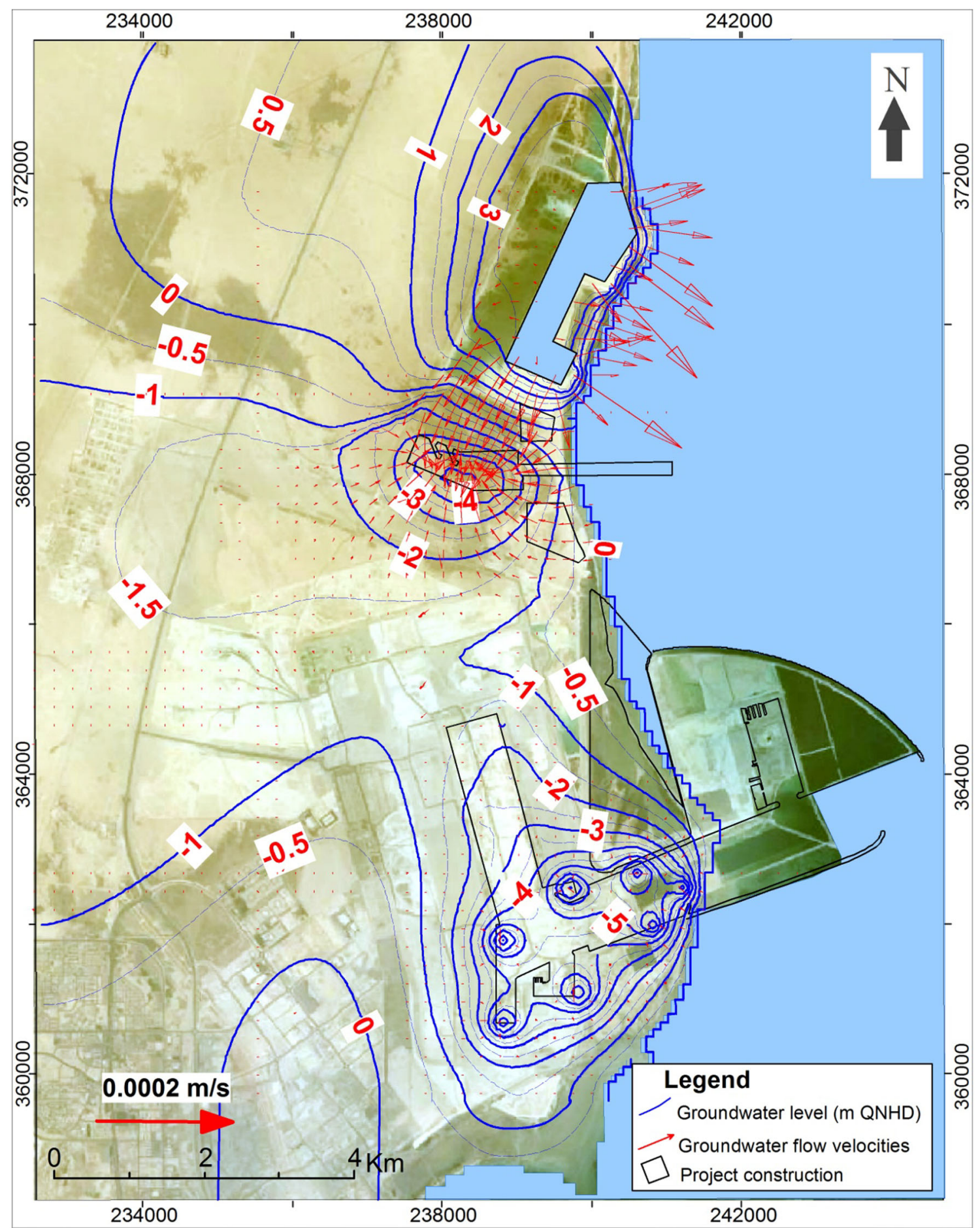

Fig. 7 Modeled groundwater piezometric map and presentation of water flow velocities in upper aquifer for scenario 1 before HBC starts of groundwater in the area of Stilling Basins (the maximum velocity calculated by the model is $0.00018 \mathrm{~m} \mathrm{~s}^{-1}$ )

dredging (September 1, 2014), showing the directions and the velocity

observed in the G3 basin and caused by the pumping water to the G3 basin.

Two important water flow velocities are presented in this scenario. The first one is from G3 to the sea. The second one is from the G3 to the QEZ3 canal. It is caused by the dewatering of the entire QEZ3 canal.

\section{Scenario 2}

Scenario 2 is characterized by three conditions: (1) The water level in stilling basins (C and D) imposed fixed-head boundary conditions to the aquifer ( $h=7 \mathrm{~m} \mathrm{CD})$, (2) Dewatering of the entire QEZ3 canal $\left(5000 \mathrm{~m}^{3} \mathrm{~h}^{-1}\right.$ which 
is estimation), and (3) dewatering of the NPP basin (the average is about $6700 \mathrm{~m}^{3} \mathrm{~h}^{-1}$ ). Scenario 2 starts in September 1, 2014 and stops in February 1, 2015 when the flooding of NPP basin starts.
Two types of fixed-head boundary conditions are applied to the groundwater in scenario 2 . In addition to the fixed-head imposed by the Sea water resistance $(\mathrm{h}=0 \mathrm{~m}$ QNHD), the two stilling basins will impose also fixed-head boundary conditions to the aquifer

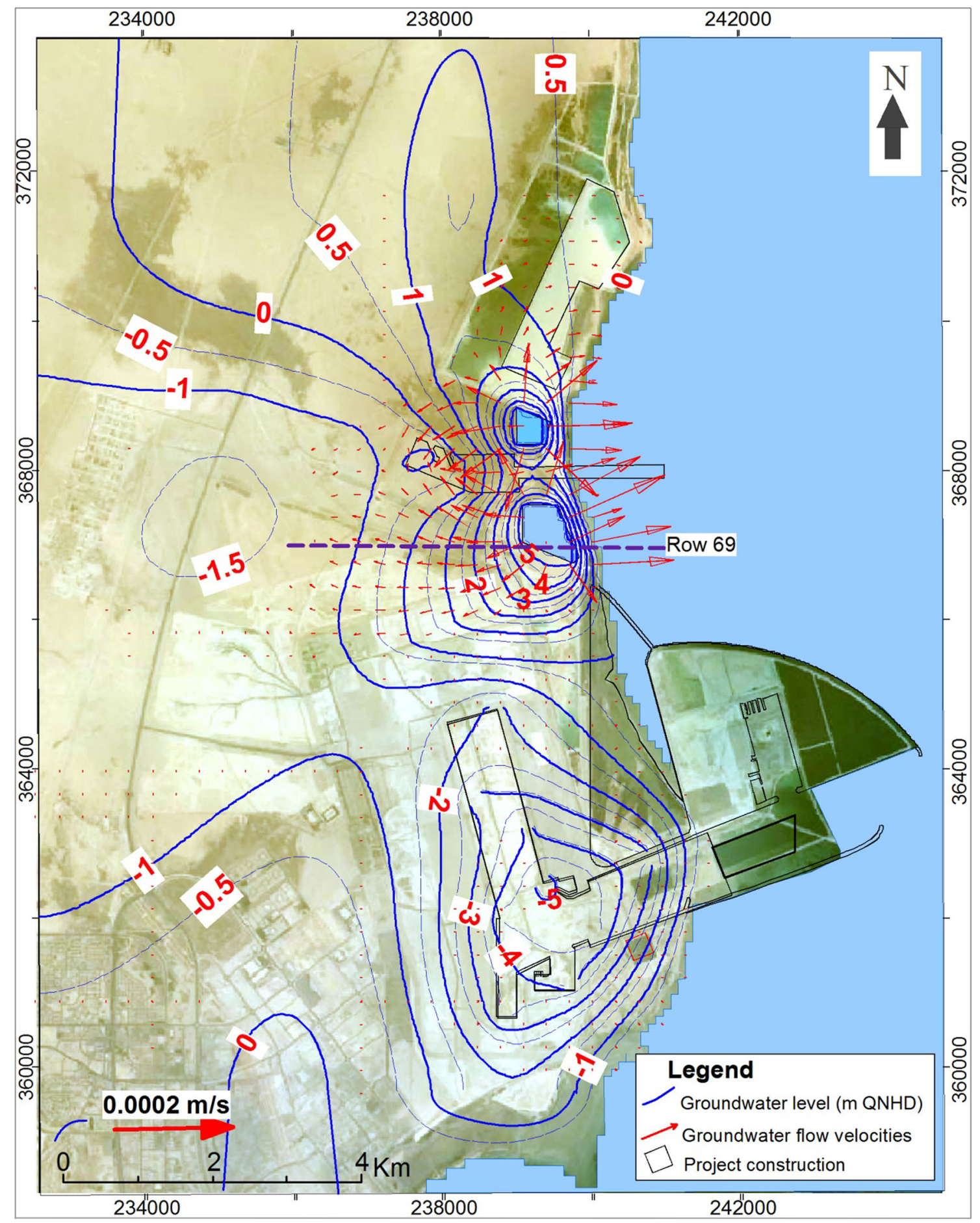

Fig. 8 Modeled groundwater piezometric map and presentation of water flow velocities in upper aquifer for scenario 2 before NPP basin starts flooded (February 1, 2015), showing the directions and the velocity of groundwater in the area of Stilling Basins (the maximum velocity calculated by the model is $0.00019 \mathrm{~m} \mathrm{~s}^{-1}$ ) 
( $\mathrm{h}=7 \mathrm{~m} \mathrm{CD}=5.7 \mathrm{~m} \mathrm{QNHD}$ ) during the dredging period (from September 2014 to May 2015).

The groundwater situation is characterized by increase in the piezometric level situated in the QEZ3 basins area (Fig. 8). The piezometric level decrease from $5.7 \mathrm{~m}$ QNHD in stilling basins to $-4 \mathrm{~m}$ QNHD in the NPP canal in the South of the aquifer. The water flow follows the North to South direction.

The hydraulic gradient is strange in the stilling basins region and decreases in the west direction. In the North and South of study region the piezometric vary between $0 \mathrm{~m}$ QNHD and $0.2 \mathrm{~m}$ QNHD. The water flow diverges from the QEZ3 stilling basins. It diverges to the sea, following the West-East direction. The water flow velocities in direction to the sea are important (Fig. 8). The calculated high piezometric level, which is more than $1.2 \mathrm{~m}$ QNHD (=2.5 $\mathrm{m} \mathrm{CD})$ and located in QEZ3 stilling basins area, can be manifested by water resurgence, especially, in the area limited by GW5, GW22, GW23 GW24, GW30 boreholes, within $2 \mathrm{~km}$ from the QEZ3 stilling basins. Figure 9 illustrates this risk in the Row 69 (located between the parallels 366,900 and 367,000 north (Fig. 8).

\section{Scenario 3}

Scenario 3 is the continuity of the scenario 1 and 2 . It is characterized by the dewatering of the entire QEZ3 canal, stilling basins (C and D), and flooding of NPP basin.

Three types of fixed-head boundary conditions are applied to the groundwater in scenario 3. In addition to the fixed-head ( $\mathrm{h}=0 \mathrm{~m}$ QNHD) imposed by the Sea, and the fixed-head ( $\mathrm{h}=7 \mathrm{~m} \mathrm{CD}=5.7 \mathrm{~m}$ QNHD) imposed by the two stilling basins, a third fixed-head ( $\mathrm{h}=0 \mathrm{~m}$ QNHD) is imposed by the NPP basin (Fig. 10).

The modeled piezometric map of May 30, 2015 (Fig. 10) is similar to the modeled piezometric map of February 1, 2015 (Fig. 9) in the entire groundwater domain, except the Southern part and the Eastern part. The piezometric level decreases from $5.7 \mathrm{~m}$ QNHD in stilling basins to $-1 \mathrm{~m}$ QNHD in the West side and the water flow follows the East-West direction. In the South part, the NNP basin imposed a fixed-head and the piezometric levels are about $0 \mathrm{~m}$ QNHD. That is explained by the importance influence of the dredging in the 2 stilling basins relatively to the NNP basin imposed fixed-head effect. And in the East part the piezometric levels increase from -1.4 (in scenario 2) to $-1 \mathrm{~m}$ QNHD (in scenario 2).

\section{Conclusions and recommendations}

The Groundwater model presents an indication of the impact of the QEZ3 project development. In fact the dewatering and flooded of NPP basin and QEZ3 canal, and the dredging from G3 and QEZ3 stilling basins causes a perturbation in the groundwater level and flow. The calculated high piezometric level, which is more than $1.2 \mathrm{~m}$ QNHD (= $2.5 \mathrm{~m} \mathrm{CD})$ situated in stilling basins area, can cause water resurgence, especially in the area limited by GW5, GW22, GW23, GW24, GW30 boreholes, within $2 \mathrm{~km}$ from the QEZ3 stilling basins.

As recommendation we propose to favorite the water flow from the two stilling basins in the direction of the sea. Two solutions can be used in this project:

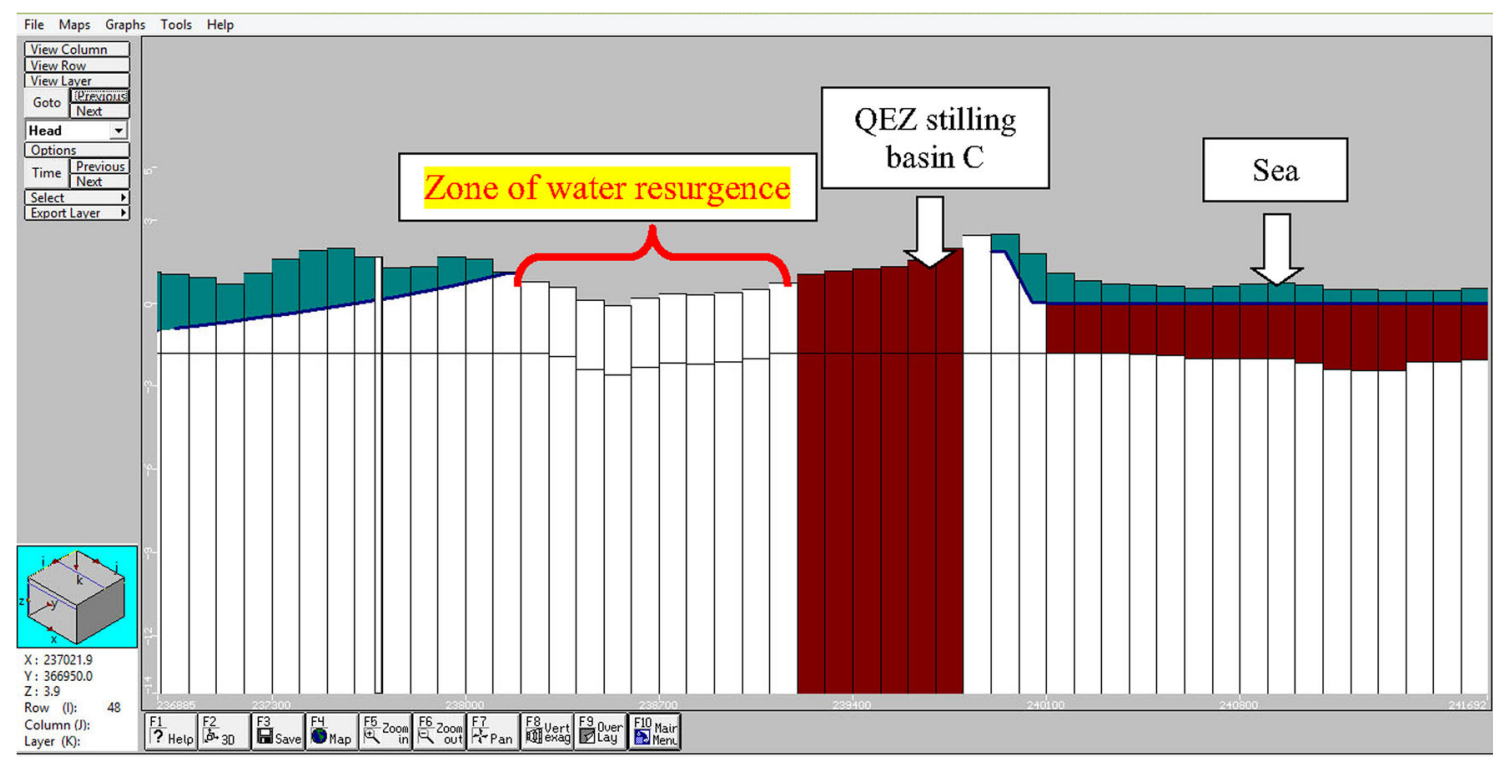

Fig. 9 Modeled groundwater piezometric profile in upper aquifer for scenario 2 before NPP basin starts flooded (February 1, 2015), Row 69 (Fig. 8) 


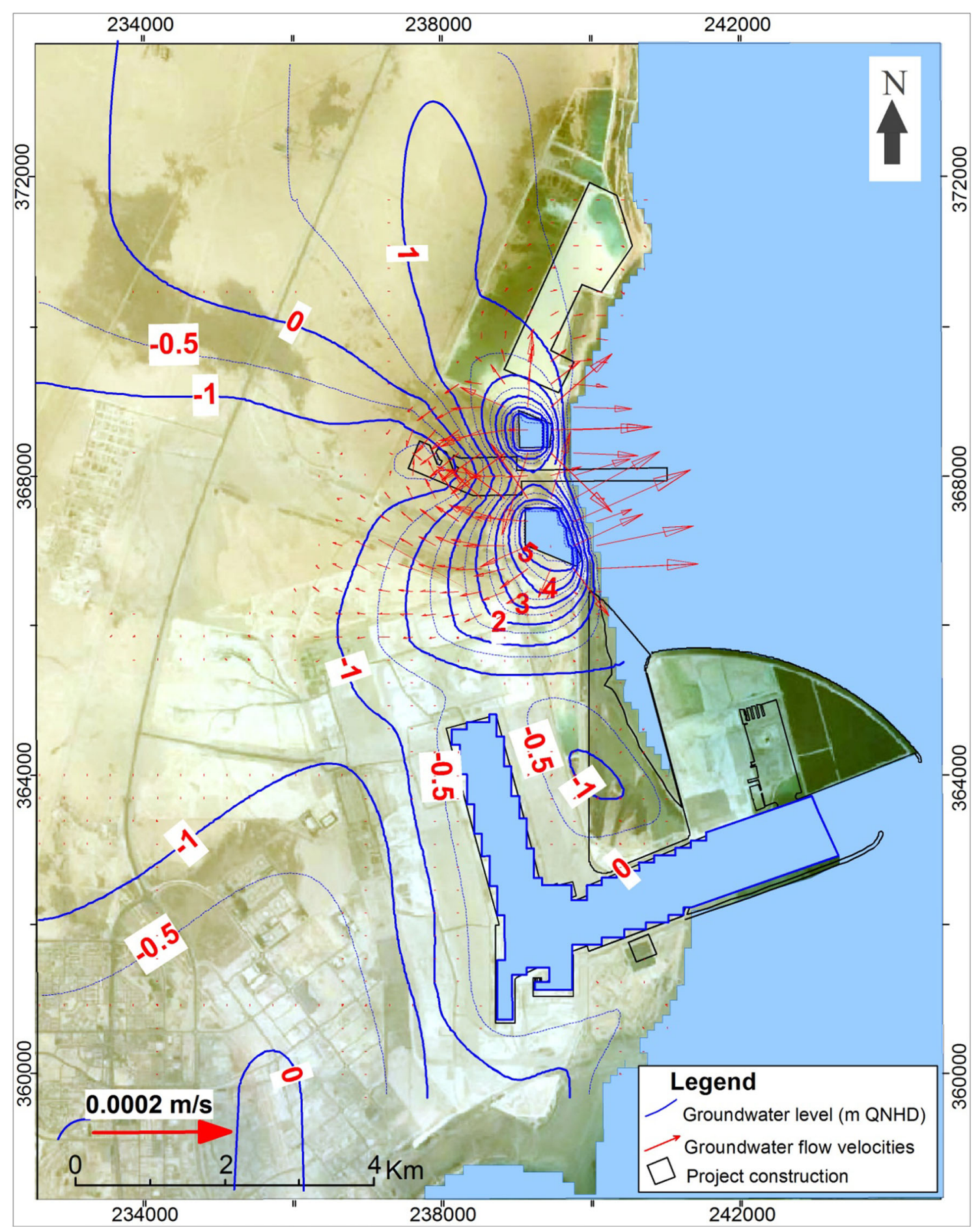

Fig. 10 Modeled groundwater piezometric map and presentation of water flow velocities in scenario 3 showing the directions and the velocity of groundwater in the area of Stilling Basins (the maximum velocity calculated by the model is $0.00019 \mathrm{~m} \mathrm{~s}^{-1}$ )

1. In addition to the stilling basin (C and D) in the QEZ3 dredging period (from September 2014 to May 2015), we propose to use the G3 basin. In this case, we will be able to decrease the level of the stilling basins $(\mathrm{C}$ and $\mathrm{D})$ from $+7.0 \mathrm{~m} \mathrm{CD}(5.7 \mathrm{~m}$ QNHD) to $5 \mathrm{~m} \mathrm{CD}$ (3.7 $\mathrm{m} \mathrm{QNHD),} \mathrm{and} \mathrm{from} 5 \mathrm{~m}$
CD (3.7 m QNHD) to $4 \mathrm{~m} \mathrm{CD}(2.7 \mathrm{~m}$ QNHD) for the G3 basin.

2. An additional drainage system can be implemented in the vicinity of the two stilling basins (C and D) in order to favorite the water flow in direction of the sea. As hydrogeological explication, the collecting 
groundwater trench around sediment basin will play the role of an artificial groundwater discharge fields.

\section{References}

Baalousha HM (2016a) Development of a groundwater flow model for the highly parameterized Qatar aquifers. Model Earth Syst Environ 2:67. doi:10.1007/s40808-016-0124-8

Baalousha HM (2016b) Using Monte Carlo simulation to estimate natural groundwater recharge in Qatar. Model Earth Syst Environ 2:87. doi:10.1007/s40808-016-0140-8

Bear J (1972) Dynamics of fluids in porous media. Dover Publications, New York. COWI's report: 01 Technical Reports\EIAISubmission\Rev1।Vol I-Vol I-EIA\P-70876-EZ3PR-05-QEZ3 Canal EIA rev 1

Calderhead AI, Martel R, Garfias J, Rivera A, Therrien R (2012) Pumping dry: an increasing groundwater budget deficit induced by urbanization, industrialization, and climate change in an overexploited volcanic aquifer. Environ Earth Sci 66:1753-1767. doi:10.1007/s12665-011-1398-9

Chambers JE, Meldrum PI, Wilkinson PB, Ward W, Jackson C, Matthews B, Joel P, Kuras O, Bai L, Uhlemann S, Gunn D (2016) Spatial monitoring of groundwater drawdown and rebound associated with quarry dewatering using automated time-lapse electrical resistivity tomography and distribution guided clustering. Eng Geol. doi:10.1016/j.enggeo.2015.05.015

Chen K, Jiao JJ (2014) Modeling freshening time and hydrochemical evolution of groundwater in coastal aquifers of Shenzhen, China. Environ Earth Sci 71:2409-2418. doi:10.1007/s12665-0132641-3

CIA (2013) The World Fact Book. Middle East: Qatar. http://www. cia.gov/library/publications/the-world-factbook/geos/qa.html. Accessed 30 April 2014

Ehteshami M, Dolatabadi Farahani N, Tavassoli S (2016) Simulation of nitrate contamination in groundwater using artificial neural networks. Model Earth Syst Environ 2:28. doi:10.1007/s40808016-0080-3

FAO (2015) Irrigation in the Middle East region in figuresAQUASTAT Survey 2008. AQUASTAT website, Food and Agriculture Organization of the United Nations (FAO). http:// www.fao.org/nr/water/aquastat/countries_regions/qat/index.stm

Gopinath S, Srinivasamoorthy K, Saravanan K, Suma CS, Prakash R, Senthilnathan D, Chandrasekaran N, Srinivas Y, Sarma VS (2016) Modeling saline water intrusion in Nagapattinam coastal aquifers, Tamilnadu, India. Model Earth Syst Environ 2:2. doi:10.1007/s40808-015-0058-6

Hashim MA (2009) Water, Agriculture and Environment in Arid Lands-Water and Agriculture Vision for Qatar By 2020

Hussien BM (2013) Modeling the impact of groundwater depletion on the hydrochemical characteristic of groundwater within Mullusi carbonate aquifer-west Iraq. Environ Earth Sci 70:453-470. doi:10.1007/s12665-012-2139-4

Jahanshahi R, Zare M (2015) Assessment of heavy metals pollution in groundwater of Golgohar iron ore mine area, Iran. Environ Earth Sci 74:505-520. doi:10.1007/s12665-015-4057-8

Jain M, Dawa D, Mehta R, Dimri AP, Pandit MK (2016) Monitoring land use change and its drivers in Delhi, India using multitemporal satellite data. Model Earth Syst Environ 2:19. doi:10. 1007/s40808-016-0075-0

Jaramillo-Nieves LG, Ge S (2012) Groundwater modeling of the Silver Bell Mountains, Arizona, USA. Environ Earth Sci 66:1933-1941. doi:10.1007/s12665-011-1418-9
Jothibasu A, Anbazhagan S (2016) Modeling groundwater probability index in Ponnaiyar River basin of South India using analytic hierarchy process. Model Earth Syst Environ 2:109. doi:10.1007/ s40808-016-0174-y

Khadri SFR, Chaitanya P (2016) Ground water flow modeling for calibrating steady state using MODFLOW software: a case study of Mahesh River basin, India. Model Earth Syst Environ 2:39. doi: 10.1007/s40808-015-0049-7

Khorasani M, Ehteshami M, Ghadimi H, Salari M (2016) Simulation and analysis of temporal changes of groundwater depth using time series modeling. Model Earth Syst Environ 2:90. doi:10. 1007/s40808-016-0164-0

Kuiper N, Rowell C, Shomar B (2015) High levels of molybdenum in Qatar's groundwater and potential impacts. J Geochem Explor 150:16-24

Lachaal F, Mlayah M, Bédir B, Tarhouni J, Leduc C (2012) Development and application of three-dimensional groundwater flow numerical model to complex aquifer system in arid and semi-arid regions using MODFLOW and GIS tools: ZéramdineBéni Hassen Miocene aquifer system (east-central Tunisia). Comput Geosci 48:187-198. doi:10.1016/j.cageo.2012.05.007

Lachaal F, Mlayah A, Anane M, Bédir M, Tarhouni J, Leduc C (2013) Comprehension and hydrogeological conceptualization of aquifer in arid and semi-arid regions using integrated hydrogeological information system: case of the deep aquifer of ZéramdineBéni Hassen (east-central Tunisia). Arab J Geosci 6(7):2655-2671. doi:10.1007/s12517-011-0498-x

McDonald RI, Green P, Balk D, Fekete B, Revenga C, Todd M, Montgomery M (2011) Urban growth, climate change, and freshwater availability. Proc Natl Acad Sci USA 108:6312-6317

McDonald RI et al (2014) Water on an urban planet: Urbanization and the reach of urban water infrastructure. Glob Environ Change 27:96-105

Mohamed Ashour M (2013) Sabkhas in Qatar peninsula. Landscape and Geodiversity, issue 1/2013, pp 10-35. ISSN 2286-0177. ICCS, Spiru Haret University

Mokarram M (2016) Modeling of multiple regression and multiple linear regressions for prediction of groundwater quality (case study: north of Shiraz). Model Earth Syst Environ 2:3. doi:10. 1007/s40808-015-0059-5

Mondal B, Das DN, Dolui G (2015) Modeling spatial variation of explanatory factors of urban expansion of Kolkata: a geographically weighted regression approach. Model Earth Syst Environ 1:29. doi:10.1007/s40808-015-0026-1

Pandey B, Joshi PK (2015) Numerical modelling spatial patterns of urban growth in Chandigarh and surrounding region (India) using multi-agent systems. Model Earth Syst Environ. doi:10. 1007/s40808-015-0005-6

Pujades E, Vázquez-Suñé E, Culí L, Carrera J, Ledesma A, Jurado A (2016) Hydrogeological impact assessment by tunnelling at sites of high sensitivity. Eng Geol. doi:10.1016/j.enggeo.2015.05.018

Sajil Kumar PJ (2016) Influence of water level fluctuation on groundwater solute content in a tropical south Indian region: a geochemical modelling approach. Model Earth Syst Environ 2:171. doi:10.1007/s40808-016-0235-2

Seyedmohammadi J, Esmaeelnejad L, Shabanpour M (2016) Spatial variation modeling of groundwater electrical conductivity using geostatistics and GIS. Model Earth Syst Environ 2:169. doi:10. 1007/s40808-016-0226-3

Shomar B, Darwish M, Rowell C (2014) What does integrated water resources management from local to global perspective mean? Qatar as a Case Study, the Very Rich Country with No Water. Water Resour Manag 28:2781-2791. doi:10.1007/s11269-0140636-9

Uddameri V, Singaraju S, Hernandez EA (2014) Impacts of sea-level rise and urbanization on groundwater availability and 
sustainability of coastal communities in semi-arid South Texas. Environ Earth Sci 71:2503-2515. doi:10.1007/s12665-0132904-Z

UN-Qatar (2009) National Vision 2030. Advancing sustainable development, Qatar Second Human Report, Qatar's second human development report, Doha, Qatar

Wang J, Feng B, Yu H, Guo T, Yang G, Tang J (2013) Numerical study of dewatering in a large deep foundation pit. Environ Earth Sci 69:863-872. doi:10.1007/s12665-012-1972-9

Wang J, Huang T, Hu J, Wu L, Li G, Yang P (2014) Field experiments and numerical simulations of whirlpool foundation pit dewatering. Environ Earth Sci 71:3245-3257. doi:10.1007/ s12665-013-2981-z

Wang J, Wu Y, Liu X, Yang T, Wang H, Zhu Y (2016) Areal subsidence under pumping well-curtain interaction in subway foundation pit dewatering: conceptual model and numerical simulations. Environ Earth Sci 75:198. doi:10.1007/s12665-0154860-2

Waterloo Hydrogeologic Inc (2003) Visual Modflow V.3.1. User's manual for professional applications in three-dimensional groundwater flow and contaminant transport modeling, $\mathrm{p} 452$

Xu B, Yan C, Sun Q, Liu Y, Hou J, Liu S, Che C (2016) Field pumping experiments and numerical simulations of shield tunnel dewatering under the Yangtze River. Environ Earth Sci 75:715. doi:10.1007/s12665-016-5493-9

Zammouri M, Jarraya-Horriche F, Odo BO, Benabdallah S (2014) Assessment of the effect of a planned marina on groundwater quality in Enfida plain (Tunisia). Arab J Geosci 7(3):1187-1203. doi:10.1007/s12517-012-0814-0 